\title{
Research
}

\section{Gender and Sustainable Forest Management in East Africa and Latin America}

\author{
$\underline{\text { Esther Mwangi }}^{1}, \underline{\text { Ruth Meinzen-Dick }}^{2}$, and $\underline{\text { Yan Sun }}^{2}$
}

\begin{abstract}
This paper presents a comparative study of forest management across four countries in East Africa and Latin America: Kenya, Uganda, Bolivia, and Mexico. It focuses on one question: Do varying proportions of women (low, mixed, high) in forest user groups influence their likelihood of adopting forest resource enhancing behavior? We found that higher proportions of females in user groups, and especially user groups dominated by females, perform less well than mixed groups or male dominated ones. We suggest that these differences may be related to three factors: gender biases in technology access and dissemination, a labor constraint faced by women, and a possible limitation to women's sanctioning authority. Mixed female and male groups offer an avenue for exploiting the strengths of women and men, while tempering their individual shortcomings.
\end{abstract}

Key Words: forest management; gender; sustainability; user groups

\section{INTRODUCTION}

Despite the fact that approaches to forest governance in many developing countries in Africa, Asia, and Latin America have undergone profound changes, for example, from central state control prior to the $1970 \mathrm{~s}$ through community-based approaches of the 1980s and the devolution of the 1990s, women's involvement in decision making has hardly kept pace. They don't fare well under forestry comanagement programs (Tinker 1994, Locke 1999, B. Agarwal 2001) or even under devolution programs (Blessings et al. 2006, Jumbe and Angelsen 2007). An improved policy environment that has potential to address gender inequity has not necessarily resulted in gains for women, even though a large and growing literature illustrates their knowledge of and dependence on forest products (Shanley and Gaia 2001, Howard 2003, Colfer 2005). Nor has their participation in decision making at household and community levels necessarily resulted in improved forest regeneration (B. Agarwal 2007, 2009) and better financial management (Acharya and Gentle 2006), including their prioritization of funding of pro-poor and empowerment programs in the forestry sector (Komarudin et al. 2008).
Women continue to be disadvantaged by insecure access and property rights to forest and tree resources (Place 1995, Meinzen-Dick et al. 1997), to discrimination and male bias in the provision of services, including credit and technology (Doss 2001, German at al. 2008), and by exclusion from decision making at household, community, and national levels (B. Agarwal 2001). Women disproportionately bear the costs of tree and forest management, realize only a fraction of the benefits, and are mostly enlisted to decision making when forest and tree resources are degraded or after conflict (Agrawal and Chhatre 2006). Moreover, because of a lack of formal education, employment, and personal networks, they are poorly placed to influence resource allocation or research priorities (Crewe and Harrison 1998). The need to understand this continued lack of involvement is urgent because women continue to be among the poorest in many developing countries and their dependence on forest resources for subsistence, as safety nets, and for incomes will assume even greater importance as forests become more threatened because of increasing global trade, climate change, urbanization, and energy and food insecurity (CIFOR 2008). The inclusion of women in resource management offers a potential pathway for empowering women both within their private and public lives (Torri 2010). 
This paper presents a comparative study of four countries in East Africa and Latin America: Kenya, Uganda, Bolivia, and Mexico. It attempts to answer the question of whether varying proportions of women (low, mixed, high) in forest user groups influence their likelihood of adopting forest resource enhancing behavior. Forest enhancing behaviors include the adoption of technologies that reduce forest dependence, e.g., bee-keeping; the application of management techniques that seek to improve forest condition, e.g., planting tree seedlings; regular monitoring and sanctioning to regulate harvesting level; and conflict management. Such behavior has been widely demonstrated to affect forest sustainability positively (Ostrom 1990).

These four countries represent a range of settings of the extent to which authority has been devolved. Kenya is a newcomer to devolution and represents the most centralized forest management of the four countries. Mexico, an early decentralizer has had the longest experience in devolving authority to communities, while Uganda and Bolivia both undertook their reforms in the 1990s and devolved to intermediate levels between the community and the state. We explore the behavior of predominantly female vs. mixed vs. predominantly male user groups with regard to forest management. Although each country situation needs to be considered on its own merits because inequalities may manifest differently, we anticipate that there are patterns and regularities across countries and settings. Few cross-national, quantitative studies have focused on gendered roles in forest management and sustainability, and even fewer have considered the effects on forest management of varying proportions of women in forest user groups. Women-only groups run the risk of isolating women, tend to lack information and exposure compared to mixed ones, and are often provided with smaller and more marginal lands as community forests (Pandey 1993, Cornwall 2001, Rai and Buchy 2004). This study advances the literature by addressing these knowledge gaps. By incorporating an analysis of varying proportions of men and women in user groups, it draws from lessons of gender mainstreaming in the past decade, which advocate for analyzing relationships between men and women, rather than women in isolation.

\section{FACTORS THAT INFLUENCE SUSTAINABLE FOREST MANAGEMENT}

A. Agrawal (2001) argues that critical factors affecting sustainable resource use include: resource characteristics, e.g., high variability, productivity, excludability; nature of the group that manages resources, e.g., size, gender, and wealth differentiation; institutional arrangements under which resources are managed, e.g., property rights, access rules, harvesting rules; and the external environment. These four categories of variables have been demonstrated, across a broad range of resource types, to affect the incentives of individuals and groups, influencing their behavior to undertake, or not, actions that may, or may not, enhance resource productivity and sustainability. For example, where resource users regularly monitor and sanction resource use, the condition of forest resources will likely be better than where rules are not enforced (Banana and Gombya-Ssembajjwe 2000, Gibson et al. 2005). Rule enforcement is positively and strongly associated with forest condition. Enforcement develops trust among individual users that other users are complying with agreed rules and that no individual is gaining advantage over others and is a necessary condition for successful resource management. However, property rights and their security, i.e., confidence that rights and benefits to forests will not be denied, also influence whether individuals or groups will invest time and effort in the sustainable management of forests (Marchetti 1997, MeinzenDick et al. 1997, Nagendra 2007). In addition, biophysical factors, such as tree species composition, elevation, aspect, and rainfall, can be just as significant as economic pressures, e.g., market access; institutions, i.e., enforcement, duration, and comanagement; demographic pressures; and gender relations, i.e., equitability of power positions between men and women, incidence of gender-related conflict, in influencing forest condition (Agrawal and Chhatre 2006).

Women are critical actors in the management of forest resources. Most gender related studies on forest sustainability are dominated by studies from India and Nepal that have focused on analyzing the impacts of community forestry. The relative participation of men and women in various capacities of decision making has been the key variable under study. Women are often excluded 
from participation for reasons including: the rules governing the community forestry groups, social barriers stemming from cultural constructions of gender roles, responsibilities and expected behavior, logistical barriers relating to the timings and length of organizational meetings, and male bias in the attitudes of those promoting community forestry initiatives (B. Agarwal 1997, 2001, 2007). For example, the rules of forest closure, which are designed to regenerate deteriorating forests, forbid entry by humans and animals. Such rules not only burden women, who subsequently have to walk further and spend longer hours collecting firewood, but also prompt them to break the rules (Sarin 1995, as cited in B. Agarwal 2007).

Despite these constraints, community forestry groupings, especially those in which women are executive officials, have performed well in regenerating degraded forest lands (B. Agarwal 2007). Higher proportions of women in forest committees increases their knowledge of group rules; is associated with stricter rules (B. Agarwal 2009); has positive effects on regulating illicit grazing and felling (A. Agrawal et al. 2004); and increases women's membership and effectiveness in community forestry groups (B. Agrawal 2010). The capacity to manage conflicts increases in groups where women are present (Westermann et al. 2005). The security of women's property rights to forest and tree resources also serves as an important incentive for their adopting resource conserving measures (Marchetti 1997, MeinzenDick et al. 1997, Kaimowitz and Angelsen 1998, Quisumbing et al. 2001); uncertainty greatly limits women's capacity to undertake action to mitigate degradation or unsustainable use (Yadama et al. 1997). Attention to gender differences in property rights can shed light on the sustainability status of forests; it is important to identify the nature of rights to forests and trees held by women and men, and how they are acquired and transmitted from one user to another (Howard and Nabanoga 2007).

The positive outcomes related to women's involvement reflect high levels of cooperation among women derived from norms of reciprocity that have developed because of work responsibilities that rely on frequent collaboration (Westermann et al. 2005). As the main and most frequent collectors of forest products, women are more familiar with the forest than men (B. Agarwal 1997). Because they are the ones responsible for feeding the family they are more burdened by deteriorating forest condition and have a tendency to want to conserve and/or to reduce pressure on forest resources in order to avoid or mitigate hardship. Men are largely involved in timber extraction unlike women who use products, e.g., firewood, nontimber forest products, that demand more frequent interaction with forests, which is also an aid to monitoring (Pandolfelli et al. 2007). They also tend to adopt practices such as environmentally friendly farming systems, e.g., terracing and taungya, cultivation of less nutrient-demanding crops, cultivation of fodder trees, or campaigns against free grazing in community forests, that lower pressures on forests (Gbadegesin 1996, Acharya and Gentle 2006). In some cases, women have actively resisted men's alienation of large forest blocks (Johnson 2003, Komarudin et al. 2008). Forestry companies and forest owners are also significantly less likely to certify their forest practices if women have little or no effective voice in civil society (van Kooten et al. 2005).

The institutional factors cited in the preceding paragraph may interact with demographic and economic attributes to influence behavior. Women's' participation in sustainable forestry management can be further conditioned by their levels of forest dependence on the biophysical quality of forest, their age and wealth levels, as well as their caste or ethnicity (Davidson-Hunt 1996, Nuggehalli and Prokopy 2009).

Jackson (1993) and Mackenzie (1995), however, caution against assuming a necessary and complementary relationship between women and sustainability because these may be constrained by the existing structure of incentives such as limited control over land, labor, and technology. Further, women, under some settings, may prefer not to engage in forest management activities either because of wealth or because they view land-based activities as backward (Jewitt 2000, Resurreccion 2006).

The review of research points to several factors that influence forest sustainability. Institutions and their enforcement are necessary factors for sustainable forest management. The attributes of resource managers, especially their gender roles, influence how forests are managed. Gender relations may further interact with rules and norms to either enhance or decrease sustainability. Other factors such as biophysical factors, wealth levels, and age are also influential. Our study explores the 
implications of gender composition in user groups on forest sustainability across forest sites in countries in East Africa and Latin America. It focuses on relative proportions of women in user groups, from low to high, and on their intermediate behaviors, i.e., whether groups adopt resource conserving behavior, or rules etc., that are in turn theorized to influence sustainability outcomes. We test the hypotheses that predominantly female and mixed user groups, i.e., user groups with higher proportions of females, in forestry settings are (1) likely to have less conflict; (2) are more likely to monitor their forests; and (3) are more likely to adopt technologies and management practices that enhance forest sustainability.

\section{METHODOLOGY}

\section{Data collection}

This study is part of a global, multidisciplinary team, the International Forestry Resources and Institutions research program (www.sitemaker.umich.edu/ifri/home ; see Chhatre and Agrawal 2009 for a detailed description of the IFRI dataset). The IFRI research protocol was used to collect data from forest sites, from settlements around each forest, and from among user groups and local organizations involved in forest management. Focus group discussions and key informant interviews were used to obtain the information on forest user group characteristics, including the number of males and females in user groups, on their forest-related activities, on property rights, and governance structures. The following questions were asked with regard to monitoring/ sanctioning, regeneration, technology, and conflicts:

- When and how do individuals in the user group interact for monitoring/sanctioning?

- Have individuals in this user group undertaken any of the following regeneration activities, and if so, how frequently: planting seedlings, planting trees, planting bushes, building fences, clearing undergrowth?

- During the past year, have any individuals in this user group invested in any of the following new technologies that improve the productivity of this forest: adopting improved bee-keeping techniques, planting seedlings that alter species mix, or other technology?
- During the last two years, have individuals in this group faced any issues that have engendered conflict within the user group?

Resource characteristics such as slope steepness were also estimated. Data was collected from 22 forest sites in Uganda, 12 in Kenya, 18 in Bolivia, and four in Mexico for a total of 56 sites in 67 forests (see Mwangi et al. 2009 for details on the forest sites, including legal status).

An IFRI forest is an area of at least 0.5 ha containing woody vegetation exploited by at least three households and governed by the same legal structure. The first visits in each of these 67 forests were conducted between 1993 and 2003. The unit of analysis is the user group: a group of people who harvest from, use, and maintain a forest and who share the same rights and duties to products from a forest. A total of 151 user groups were used for this analysis.

\section{Empirical model}

\section{The dependent variables}

We use the following four dependent variables to approximate user group behavior:

- Monitoring and sanctioning: 1 = regular monitoring and sanctioning, i.e., year round or seasonally, $0=$ otherwise.

- Regeneration activities: 1 = user groups undertake any of the following regeneration activities regularly, at least once a year: plant seedlings, trees, bushes, build fences, and clear undergrowth, $0=$ otherwise.

- Technology: 1 = individuals in the user group undertook any of the following technologies to improve the productivity of the forest: adopting improved bee-keeping techniques, planting seedlings that alter species mix, or other technologies, $0=$ otherwise.

- Conflict: 1 = individuals faced any issues that have engendered conflict within the user group, $0=$ otherwise. 


\section{The model}

Because the dependent variables are binomial, we used probit regressions. For example, consider monitoring and sanctioning. Let $y_{\mathrm{i}}{ }^{*}$ stand for the true probability associated with monitoring and sanctioning by user group $i$. The following is the regression equation:

$$
y_{i}^{*}=\beta^{\prime} x_{i}+\varepsilon_{i}
$$

$\mathrm{B}$ is a vector of coefficients we are going to estimate, $x_{i}$ is the vector of our observed explanatory variables for the user group $i$, and $\varepsilon_{i}$ is the vector of normally distributed residual terms with $\mathrm{E}\left(\varepsilon_{i}\right)=0$.

Because true probability $y_{\mathrm{i}}^{*}$ is unobserved, and what we observed are two discrete choices: the user group did regular monitoring and sanctioning, if the probability is positive, or not, if the probability is negative. Let $y_{\mathrm{i}}$ be the observed outcome which follows:

$$
y_{i}=\left\{\begin{array}{l}
1 \text { if } y_{i}^{*} \geq 0 \\
\text { we observe the user group did monitoring } \\
\text { and sanctioning regularly } \\
0 \text { if } y_{i}^{*}<0 \\
\begin{array}{l}
\text { we observe the user group not doing monitoring } \\
\text { and sanctioning regularly }
\end{array}
\end{array}\right.
$$

The probit model is as follows:

$$
\operatorname{Prob}\left(y_{i}=1\right)=\operatorname{Prob}\left(y_{i}^{*} \geq 0\right)=\int_{-\infty}^{\beta^{\prime} x_{i}} \frac{1}{\sqrt{2 \pi}} e^{-\frac{t^{2}}{2}} d t
$$

The marginal effect is as follows:

$$
\frac{\partial E\left(y_{i} \mid x_{i}\right)}{\partial x_{i j}}=\frac{\partial F\left(x_{i}^{\prime} \beta\right)}{\partial x_{i j}}=f\left(x_{i}^{\prime} \beta\right) \beta_{j}
$$

Where $\mathrm{f}$ (.) is a probability density function (P.d.f.) of a standard normal distribution, $\beta_{j}$ denotes the jth element of $\beta$ and $x_{i j}$ denotes the jth element of $x_{i}$.

\section{The explanatory variables}

We include three types of explanatory variables: resource characteristics, user group characteristics, and governance arrangements. Definitions of the variables are given in Table 1 while their descriptive statistics are presented in Table 2.

The resource characteristics include the (log of) size of the forest area in hectares and a categorical variable for topography, which ranges from flat to steep topography. As indicated in Table 2, the size of the forest varied considerably in all of the four countries.

The characteristics of the user groups include the distance that users live from the forest, the log of user group membership size, a dummy variable for wealth heterogeneity, proportion of female members, and duration of the user group's existence, i.e., $\log$ of years since formation. The majority of the user groups lived either in the forests or close to the forests. The size of the user groups varied enormously, from a couple of members to thousands of members, with an average of 766 members. About $41 \%$ of the user groups thought there was large wealth differences among them. On average, $37 \%$ of the members of the user groups were female. The mean of the user group duration was 75 years, but this average is skewed by one very old user group.

The relationship of the group with the forest owner is indicated by a dummy variable with a value of 1 if the forest owner is a member of the user group, and 0 otherwise. Very few (14\%) of the user groups included the owner of the forest. Finally, two property rights variables were included among the group characteristics. Property rights of the user groups are indicated by a dummy variable that equals 1 if the group has the right to harvest trees from the forest. Property rights of others are indicated by another dummy variable with a value of 1 if there are other groups sharing the forest. About $58 \%$ of the user groups had the right to harvest trees from the forest, either by directly felling live trees or by collecting fallen ones. About $90 \%$ of the user groups reported that other user groups also had the right to harvest forest product from their own forest.

Governance arrangements include formal ownership of the forest land, external enforcement institutions, exclusion rules, and property rights of the forest owners. Forest ownership is designated by a series of dummy variables for ownership by the national government, local government, village, other multiple ownership, and private ownership. About $68 \%$ of the forests belong to the national government, about $8 \%$ belong to the local government, another $8 \%$ belong to the villages and settlements, $5 \%$ belong to the private individuals and families, and $1 \%$ belongs to other types of multiple ownerships. 
Table 1. Definition of explanatory variables.

\begin{tabular}{ll}
\hline \hline Variable Name & Variable Definition \\
\hline Resource characteristics & \\
Forest size & $\log$ of forest size (unit of forest size in hectares) \\
Topography & $\begin{array}{l}\text { topography of forest land:1=primary flat; } 2=\text { mostly flat with some rolling terrain; } 3= \\
\text { primarily rolling terrain; } 4=\text { mostly rolling terrain with some steep portions; } 5=\text { primarily } \\
\text { steep }\end{array}$
\end{tabular}

\section{User group characteristics}

Distance

Member size

Wealth heterogeneity

Gender factor: male group

Gender factor: mixed group

Gender factor: female group

Duration of user group

\section{Governance Arrangements}

Ownership of the forest land

Owned by national govt.

Owned by local govt.

Owned by village

Owned by other multiples

Owned by private

\section{External Enforcement}

Forest specific organizations

Government organizations

Community organizations

Private organizations

\section{Property rights}

Including owner how far away do user groups live from forest: $1=$ within $1 \mathrm{~km} ; 2=1$ to $5 \mathrm{~km} ; 3=5$ to $10 \mathrm{~km}$; $4=$ more than $10 \mathrm{~km}$

log of user groups' size (group size is total number of individuals in a user group)

dummy, $1=$ there is large wealth difference among households in the user groups; $0=$ otherwise

Dummy, $1=$ proportion of female members $<33 \%$

Dummy, $1=$ proportion of females $33 \%$ to $66 \%$

Dummy, $1=$ proportion of females $>66 \%$

three groups: newly formed groups $(=<10$ years old); mature groups (10-30 years old); old groups ( $>30$ years old)

dummy, $1=$ national govt.; $0=$ not national govt.

dummy, $1=$ local govt.; $0=$ not local govt.

dummy, $1=$ villages; $0=$ not villages

dummy, $1=$ other multiple ownerships; $0=$ not other ownerships

dummy, $1=$ private ownership; $0=$ not private ownership

total number of forest-specific government organizations in the forest/1000 ha

total number of other government organizations in the forest/1000 ha

total number of community based organizations in the forest/1000 ha

total number of private organizations external to the forest/1000 ha

dummy, $1=$ the user group includes the owner of the forest, if privately owned; $0=$ otherwise 
Owner right

User rights

Use rights of other user groups

Regional effect-Latin America

Regional effect—Africa dummy, $1=$ legal owner of the forest has the right harvest forest product; $0=$ otherwise

dummy, $1=$ the user group has the right to harvest trees from the forest; $0=$ otherwise

dummy, $1=$ other groups harvesting this forest; $0=$ otherwise

dummy, 1=Latin America, 0=otherwise

dummy, $1=$ Africa, $0=$ otherwise
External enforcement includes four categories of external organizations that may be involved in enforcing forest rules: government forestry related organizations, other government organizations, community-based, and private organizations. We standardized external enforcements into total number of organizations per 1000 hectares of the forest land, and the average value is about five organizations of each type per 1000 hectare of the forest land.

Property rights of the owner are designated by a dummy variable with a value of 1 if the owner has the right to harvest product. Two-thirds of the forest owners had the rights to harvest all of the forest products. Finally, dummy variables were included to control for region (Africa vs. Latin America).

Descriptive analyses of each of these variables were conducted and are presented in Mwangi et al. 2009. They suggest that even though user groups with higher proportions of women may tend to have less conflict, they are less likely to engage in regular monitoring of the forest resource and also unlikely to engage in various activities and technologies that enhance the forest's overall productivity or condition. These results are further explored in a regression analysis that includes other relevant factors that the literature identified as important in affecting resource sustainability.

\section{RESULTS AND DISCUSSION}

As indicated in Table 3, female dominated user groups are less likely to adopt forest improving technologies relative to the male dominated ones. The probability of investing in new technology is reduced by $25 \%$ for female dominated user groups compared with male dominated ones, while keeping all other variables constant at the sample mean. ${ }^{[1]}$ In forests characterized by steeper topography, more government organizations, and fewer community and private forest organizations, user groups tend to adopt technologies that improve forest productivity. User groups in Kenya and Uganda that used forests owned by national government, as opposed to local governments in Bolivia and Mexico, tend to adopt such technologies. User groups in Latin America are more likely to invest in new technology than user groups in Africa.

Gender does not seem to affect the regularity with which user groups undertook regeneration activities in the forest, even though mixed and male dominated groups had higher reporting of regular regeneration activities. However, user groups in Latin America, where about $85 \%$ of forests are mostly owned by local governments and communities, are significantly more likely to undertake regeneration activities in their forests than their counterparts in East Africa where about $96 \%$ of all forests sampled in the study are stateowned.

Mixed groups tend to do more monitoring than male-dominated ones, and female-dominated ones are unlikely to conduct any monitoring at all. Where forest topographies are steeper, user groups are more likely to monitor forest resources, just as when there are more government organizations concerned with forestry. Private organizations, however, tend to diminish user group monitoring. Newly formed groups have more regular monitoring than the mature groups, while the further away user groups are from the forest, the less likely they are to undertake forest monitoring. In addition, user groups that have the right to harvest trees are less likely to monitor their forests. Property rights also influence the likelihood of monitoring: user groups in forests owned by local government are less likely to monitor than those in national government forests, while private ownership increases the 
Table 2. Descriptive statistics of explanatory variables.

\begin{tabular}{|c|c|c|c|c|c|}
\hline Variable Name & Definition & Observation & Mean & Minimum & Maximum \\
\hline \multicolumn{6}{|l|}{ Resource characteristics } \\
\hline Size & forest size (unit is hectares) & 155 & 3848 & 20.8 & 44,900 \\
\hline Topography & forest topography & 156 & 3.32 & 1 & 5 \\
\hline \multicolumn{6}{|l|}{ User group characteristics } \\
\hline Distance & distance of user groups from forest & 156 & 1.82 & 1 & 4 \\
\hline Member size & user group size & 164 & 766 & 6 & 27,000 \\
\hline Wealth heterogeneity & wealth difference & 160 & 0.41 & 0 & 1 \\
\hline Female prop. & proportion of female members & 162 & 0.37 & 0 & 1 \\
\hline Duration & years since group formation & 135 & 75 & 0 & 599 \\
\hline Including owner & user groups including forest owner & 161 & 0.14 & 0 & 1 \\
\hline User right & user group's right to harvest & 142 & 0.58 & 0 & 1 \\
\hline User right of other groups & other group's right to harvest & 156 & 0.9 & 0 & 1 \\
\hline \multicolumn{6}{|l|}{ Governance Arrangements } \\
\hline Owned by nat & land owner is national govt. & 164 & 0.68 & 0 & 1 \\
\hline Owned by loc & land owner is local govt. & 164 & 0.08 & 0 & 1 \\
\hline Owned by vil & land owner is villages & 164 & 0.08 & 0 & 1 \\
\hline Owned by other mul. & land owner is other multiple owners & 164 & 0.1 & 0 & 1 \\
\hline Owned Pri. & land owner is private & 164 & 0.05 & 0 & 1 \\
\hline Forest Org. & forest-specific govt. organizations & 126 & 6.62 & 0 & 73 \\
\hline Gov. Org. & other govt. organizations & 137 & 4.71 & 0 & 87 \\
\hline Com. Org. & community-based organizations & 126 & 5.72 & 0 & 100 \\
\hline Pri. Org. & private organizations & 126 & 4.71 & 0 & 87 \\
\hline Owner right & Forest owner's right to harvest & 166 & 0.67 & 0 & 1 \\
\hline
\end{tabular}


Table 3. Probit estimates of user groups' behavior.

\begin{tabular}{|c|c|c|c|c|c|c|c|c|}
\hline \multirow[t]{2}{*}{ Independent Variables } & \multicolumn{2}{|c|}{ New Technology } & \multicolumn{2}{|c|}{ Regeneration } & \multicolumn{2}{|c|}{ Monitoring } & \multicolumn{2}{|c|}{ Conflicts } \\
\hline & Coef. & Z Stat. & Coef. & Z Stat. & Coef. & Z Stat. & Coef. & Z Stat. \\
\hline \multicolumn{9}{|l|}{ Resource Characteristics } \\
\hline $\begin{array}{l}\text { Topography dummies }(1= \\
\text { flat, } \ldots, 5=\text { steep })\end{array}$ & 0.4007 & $2.03 * *$ & 0.0151 & 0.07 & 1.4818 & $2.17 * *$ & 0.8365 & $2.59 * * *$ \\
\hline Log of forest size (hectare) & 0.0172 & 0.09 & 0.1743 & 1.01 & -0.2591 & -0.61 & 0.5548 & $2.05 * *$ \\
\hline \multicolumn{9}{|l|}{ External Enforcement } \\
\hline $\begin{array}{l}\text { Government organizations } \\
(\# / 1,000 \text { hectares })\end{array}$ & 0.2453 & $1.97 * *$ & 0.0875 & 1.11 & 0.6722 & $2.69 * * *$ & 0.7933 & $3.29 * * *$ \\
\hline $\begin{array}{l}\text { Community-based } \\
\text { organizations (\#/hectares) }\end{array}$ & -0.1507 & $(-1.78)^{*}$ & -0.0839 & -1.54 & 0.0554 & 0.29 & -0.6093 & $(-3.98)^{* * *}$ \\
\hline $\begin{array}{l}\text { Forest specific organizations } \\
\text { (\#/hectares) }\end{array}$ & 0.0941 & 1.34 & 0.0342 & 1.22 & -0.5809 & $(-2.45)^{* *}$ & 0.0939 & $2.82 * * *$ \\
\hline $\begin{array}{l}\text { Private organizations (\#/ } \\
\text { hectares) }\end{array}$ & -0.2342 & $(-1.78)^{*}$ & -0.0212 & -0.43 & -0.5974 & $(-3.35)^{* * *}$ & 0.0733 & 1.22 \\
\hline \multicolumn{9}{|l|}{ Internal Enforcement } \\
\hline $\begin{array}{l}\text { dummy, local gov owned forest } \\
\text { land (ref=nat. gov) }\end{array}$ & -3.1992 & $(-2.34)^{* *}$ & -1.0713 & -1.10 & -5.8743 & -1.61 & . & . \\
\hline $\begin{array}{l}\text { dummy, village owned forest } \\
\text { land (ref=nat. gov) }\end{array}$ & -1.9432 & -0.86 & . & . & 2.6551 & 1.28 & . & . \\
\hline $\begin{array}{l}\text { dummy, privately owned forest } \\
\text { land (ref.=gov) }\end{array}$ & . & . & . & . & 14.2013 & $3.34 * * *$ & . & . \\
\hline \multicolumn{9}{|l|}{ Forest level governance } \\
\hline $\begin{array}{l}\text { Forest owner have right to } \\
\text { harvest product ( } 1=\text { yes })\end{array}$ & 0.2058 & 0.34 & 0.9738 & -1.11 & -0.0372 & -0.04 & -1.0486 & $(-1.72)^{*}$ \\
\hline $\begin{array}{l}\text { Other group harvest from this } \\
\text { forest ( } 1=y \text { es })\end{array}$ & -0.1484 & -0.16 & 5.2794 & $(1.95)^{*}$ & . & . & . & . \\
\hline \multicolumn{9}{|l|}{ User groups' characteristics } \\
\hline $\begin{array}{l}\text { Distance to forest }(1=\text { within } \\
1 \mathrm{~km}, \ldots, 4=>10 \mathrm{~km})\end{array}$ & 0.6002 & 1.23 & -0.1872 & -0.62 & -2.9045 & $(-3.35) * * *$ & -0.3997 & -0.65 \\
\hline $\begin{array}{l}\text { Log of group size (num. of } \\
\text { ind.) }\end{array}$ & 0.0525 & 0.48 & 0.1832 & 1.47 & -0.1204 & $(-0.76)$ & 0.0321 & 0.27 \\
\hline
\end{tabular}




\begin{tabular}{|c|c|c|c|c|c|c|c|c|}
\hline $\begin{array}{l}\text { Age of the user group (bt. } 10 \\
\text { and } 30 \text { years })(\text { ref }<=10 \mathrm{yr})\end{array}$ & 0.5114 & 0.66 & -0.2224 & -0.33 & -3.1949 & $(-2.03)^{* *}$ & -1.5593 & $(-1.92)^{*}$ \\
\hline $\begin{array}{l}\text { Age of the user group (older } \\
\text { than } 30 \mathrm{yrs})(\text { reg. }<=10 \mathrm{yrs})\end{array}$ & 0.0045 & 0.01 & -0.2179 & -0.46 & 0.1181 & 0.13 & -1.9181 & $(-3.22)^{* * *}$ \\
\hline $\begin{array}{l}\text { dummy, user group includes } \\
\text { owner of forest (1=yes) }\end{array}$ & 1.6989 & 1.59 & . & . & . & . & . & \\
\hline $\begin{array}{l}\text { User groups have right to } \\
\text { harvest trees }(1=\text { yes })\end{array}$ & 0.7144 & 1.27 & -0.0427 & -0.08 & -2.7306 & $(-2.78)^{* * *}$ & 0.3372 & 0.44 \\
\hline $\begin{array}{l}\text { wealth heterogeneity in the user } \\
\text { groups (1=yes) }\end{array}$ & 0.1611 & 0.43 & -0.0391 & -0.09 & 6.0515 & $3.29 * * *$ & 2.3613 & $3.68 * * *$ \\
\hline \multicolumn{9}{|l|}{ Gender factor } \\
\hline $\begin{array}{l}\text { Mixed group dummy (ref=male } \\
\text { dominated) }\end{array}$ & -0.7153 & -1.29 & -0.3018 & -0.58 & 3.0567 & $3.91 * * *$ & 0.2498 & 0.47 \\
\hline $\begin{array}{l}\text { Female dominated group } \\
\text { dummy (ref=male dom.) }\end{array}$ & -1.2942 & $(-1.71)^{*}$ & -0.7058 & -1.12 & . & . & 1.7102 & 1.61 \\
\hline \multicolumn{9}{|l|}{ Regional fixed effect } \\
\hline $\begin{array}{l}\text { Latin American region dummy } \\
\text { (ref=Africa) }\end{array}$ & 3.2633 & $2.93 * *$ & 3.2821 & $4.65^{* * *}$ & 4.4039 & 1.45 & 0.0653 & 0.06 \\
\hline Constant & -3.9209 & $(-2.01)^{* *}$ & -7.8812 & $(-2.06)^{* *}$ & -2.9687 & -1.07 & & \\
\hline Number of observation & 66 & & 74 & & 56 & & 73 & \\
\hline Wald Chi2 & 50.41 & & 68.45 & & 56.51 & & 57.19 & \\
\hline Prob $>$ chi 2 & 0.0001 & & 0.0000 & & 0.0000 & & 0.0000 & \\
\hline Pseudo R2 & 0.3662 & & 0.4815 & & 0.6073 & & 0.6296 & \\
\hline
\end{tabular}

Note:

(i) $* * *, * *$, and $*$ respectively represent significance at $1 \%, 5 \%$, and $10 \%$.

(ii) Standard errors are robust to heteroskedasticity.

(iii) For the new technology regression, two kinds of internal enforcement (other types of forest land and privately ownership) are not included in the regression because of perfect prediction of explanatory variables.

(iv) For the regeneration regression, three kinds of internal enforcement and forest owner dummy are not included in the regression because of identification problem.

(v) For the monitoring regression, one internal enforcement (other types of ownership), forest owner dummy, dummy of other group's access, and female dominated group dummy are not included in the regression because of the identification problem.

(vi) For the conflict regression, all the internal enforcement dummies, forest owner dummy, and dummy of other group's access are not included in the regression because of identification problem. 
likelihood of monitoring. Differences in wealth also tend to improve the likelihood of forest monitoring.

Gender does not significantly affect the incidence of conflicts in user groups. An increasing number of community organizations reduces the probability of conflicts among user groups, while the presence of forest based organizations and government organizations tends to increase it. Conflicts have a lower probability where forest owners have the right to harvest forest products. Wealth heterogeneity, forest size, and steep topography tend to increase the likelihood of conflicts among user groups. Mature groups report less conflict than newly formed groups, and old groups report even less conflict than mature groups. However, there is no regional difference in the incidence of conflict among user groups.

The gender dimensions of the above results depart from our theoretical expectations. We had anticipated that higher proportions of women in user groups would increase the likelihood of such user groups adopting governance arrangements and technologies that are in turn expected to improve resource sustainability. How might we account for these findings?

A broad literature on natural resources management in developing countries suggests that extension work, the main means through which new technologies are disseminated to rural populations, is gender biased (Doss 2001). In recent work in Ethiopia for example, German et al. (2008) found that female-headed households had never been visited by agricultural extension officers, unlike male farmers who got regular visitations. Extension agencies are mostly staffed by males, not dissimilar from findings in other settings (Odebode 2005). Traditionally forest management has been associated with timber, a product of commercial value that is often traded in markets largely by males. It would thus not be surprising if forest extension officials were biased toward males. In addition, many technologies that remove pressure from forests such as bee keeping and seedling planting require the purchasing of equipment or seedlings, and women often have less control over cash. Without additional support, women are disadvantaged in the uptake of such technologies. It is thus unsurprising that predominantly women's user groups are less likely to adopt such technologies.
Even though statistically insignificant, predominantly women's groups reported less incidences of undertaking regeneration activities such as tree planting or clearing undergrowth than predominantly male and mixed groups. These activities are labor and time intensive and may require specialized knowledge depending on the tree species. Increasing the survival rates of seedlings requires regular monitoring, including frequent watering, the application of manure, and protection from birds and other animals. It is unlikely that women, who are already engaged in productive and reproductive activities, will have the necessary time and labor to spare for this additional activity (Cleaver and Schreiber 1997, Ahmed and Laarman 2000, Ejembi et al. 2006). Moreover, some forestry activities such as tree planting, weeding, and protection often require physical exertion and men have been noted to differentially participate in them (Oloruntoba and Adetokunbo 2006).

The same labor constraint hypothesis may apply in any account that seeks to explain why predominantly female user groups perform poorly in monitoring and sanctioning than do mixed and predominantly male groups, especially because of distances to be covered and the perceived dangers of patrolling the forest or fears of women's harassment by local forestry officials (Watkins 2009). Alternatively, it may reflect a gendered disparity on whose authority counts in sanctioning infractions possibly because women prefer not to jeopardize their social networks through sanctioning because they may be more dependent on these networks than men (L. Pandolfelli, personal communication).

Although conflict appears insignificant across our three categories of user groups, the descriptive analysis suggests that a higher proportion of women in user groups decreases the incidence of conflict in user groups. This result is consistent with Westermann et al. (2005) who demonstrate that women are more likely to have stronger norms of solidarity given their tendency to cooperate in other spheres of their lives.

It is unclear why there exists a differential in women's participation between the two Latin American countries and the East African ones. Bolivia and Mexico had no women's only groups, whereas East Africa had a few. In both regions, however, the older forest user groups had a higher proportion of females than the newer ones, which 
may suggest some as yet unknown barriers to entry that may relax as the user group matures.

\section{CONCLUSION}

We began this exploration by asking whether varying proportions of women (low, mixed, high) in forest user groups influence their likelihood of adopting forest resource enhancing behavior across four countries in Africa and Latin America. A review of the literature suggests that because women are more dependent on forest resources, spend more time in the forest, and have built strong norms of cooperation, they are more likely to display behaviors, e.g., governance arrangements and technology adoption, that have a positive effect on forest sustainability. The literature also suggests other critical factors that may influence resource sustainability and decision making such as resource characteristics, human capital, external organizations, and property rights. We accounted for these factors in our analysis to establish the magnitude and direction of our gender variable. We found that higher proportions of females in user groups, and especially user groups dominated by females, perform less well than mixed groups or male dominated ones. We have suggested that these differences relate to gender biases in technology access and dissemination, with a labor constraint faced by women who are at once a source of labor in family farms, caregivers in families, and who face a possible limit in their sanctioning authority.

What do we learn from this initial exploration? This study strengthens the plea against essentializing women as 'natural conservators.' It suggests that mixed groups appear to offer an avenue for exploiting the strengths of women and men, while tempering their individual shortcomings. Mixed groups, which already exist, can for example, take advantage of men's capacity to adopt new technologies and resource management and monitoring practices, while benefiting from women's capacities to manage conflict and enhance cooperation. Sultana and Thompson (2006) found that mixed-sex groups were more effective at monitoring than women's groups because men were able to patrol fishponds at night when it was physically less safe for women to do so. However, this does not detract from the obvious need to ensure that men and women in mixed groups engage in functional and effective partnerships that do not undermine the authority of either. Our results also suggest that technologies that reduce pressures on forests be targeted at women in ways that will facilitate their adoption, for example by ensuring that extension visits to user groups be undertaken by both mixed groups of agents or by raising awareness of, and providing requisite skills, among male agents of the sustainability benefits of proactively engaging women resource users. Moreover, such technologies should be designed to take into account women's time constraints. Finally, extension should be accompanied by training in the skills necessary for ensuring and sustaining technology adoption (see Agbogidi and Ofuoku 2009 , for an account of how women's training influences their participation in forestry activities).

Further research is required to establish the exact division of labor, the nature and extent of cooperation, the flows of information, knowledge, and benefits, and leadership between male and female participants of mixed forest user groups prior to the deployment of interventions that encourage them. Importantly, a systematic exploration of why women tend to populate older user groups more than younger ones is necessary.

Responses to this article can be read online at:

http://www.ecologyandsociety.org/voll6/iss 1/art17/ responses/

\section{Acknowledgments:}

Helpful comments were received from Pauline Peters, Lorenzo Casaburi, participants of the Sustainability Science Fellows seminar, Harvard University, and panelists and participants at the IFRI panels in the Forest Governance session of the 12th Biennial Conference of the International Association for the Study of the Commons, 2009, Cheltenham, England. The authors also acknowledge the support of the United States Agency for International Development's Sustainable Agriculture and Natural Resources Management Collaborative Research Support Program under terms of Cooperative Agreement Award No. EPPA-00-04-00013-00, as well as the support of Harvard University's Sustainability Science Program and the Center for the Environment. Guidance of two anonymous reviewers is greatly appreciated. 


\section{LITERATURE CITED}

Acharya, K. P., and P. Gentle. 2006. Improving the effectiveness of collective action: sharing experiences from community forestry in Nepal. Collective Action and Property Rights (CAPRi) Working Paper No. 54. International Food Policy Research Institute, Washington, D.C., USA.

Agarwal, B. 1997. Environmental action, gender equity and women's participation. Development and Change 28(1):1-44.

Agarwal, B. 2001. Participatory exclusions, community forestry, and gender: an analysis for south Asia and conceptual framework. World Development 29(10):1623-1648.

Agarwal, B. 2007. Gender inequality, cooperation, and environmental sustainability. Pages 274-313 in J. M. Baland, P. K. Bardhan, and S. Bowles, editors. Inequality, cooperation, and environmental sustainability. Russell Sage Foundation and Princeton University Press, New York, New York, and Princeton, New Jersey, USA.

Agarwal, B. 2009. Gender and forest conservation: the impact of women's participation in community forest governance. Ecological Economics 68 (11):2785-2799.

Agarwal, B. 2010. Does women's proportional strength affect their participation? Governing local forests in South Asia. World Development 38(1):98112.

Agrawal, A. 2001. Common property institutions and sustainable governance of resources. World Development 29(10):1649-1672.

Agrawal, A., and A. Chhatre. 2006. Explaining success on the commons: community forest governance in the Indian Himalaya. World Development 34(1):149-166.

Agrawal, A., G. Yadama, R. Andrade, and A. Bhattacharya. 2004. Decentralization, community, and environmental conservation: joint forest management and effects of gender equity in participation. Collective Action and Property Rights (CAPRi) Working Paper No. 63. International Food Policy Research Institute, Washington, D.C., USA.
Agbogidi, O. M., and A. U. Ofuoku. 2009. Extension and forestry development training for rural women on forest exploitation. ARPN Journal of Agricultural and Biological Science 4(5):14-18.

Ahmed, M. R., and J. G. Laarman. 2000. Gender equity in social forestry programs in Bangladesh. Human Ecology 28(3):433-450.

Banana, A. Y., and W. Gombya-Ssembajjwe. 2000. Successful forest management: the importance of security of tenure and rule enforcement in Ugandan forests. Pages 87-98 in C. Gibson, M. McKean, and E. Ostrom, editors. People and forests: communities, institutions, and governance. MIT Press, Cambridge, Massachusetts, USA.

Blessings, C., L. Jumbe, and A. Angelsen. 2006. Do the poor benefit from devolution policies? Evidence from Malawi's forest co-management program. Land Economics 82(4):562-581.

Center for International Forestry Research (CIFOR). 2008. CIFOR's strategy, 2008-2018: making a difference for forests and people. Center for International Forestry Research, Bogor, Indonesia. [online] URL: http://www.cifor.cgiar.org/ publications/pdf files/Books/CIFORStrategy0801. pdf.

Chhatre, A., and A. Agrawal. 2009. Synergies and trade-offs between carbon storage and livelihood benefits from forest commons. Proceedings of the National Academy of Sciences 106:17667-17670.

Cleaver, K., and G. Schreiber. 1997. Population, agriculture and the environment in Africa. Finance and Development 29(2):34-35

Colfer, C., editor. 2005. The equitable forests: diversity, community and resource management. Resources for the Future and CIFOR, Washington, D.C., USA.

Cornwall, A. 2001. Making a difference? Gender and participatory development. IDS Discussion Paper No. 378. Institute of Development Studies, Brighton, UK.

Crewe, E., and E. Harrison. 1998. Whose development? An ethnography of aid. Zed Books, London, UK. 
Davidson-Hunt, K. 1996. Gender and forest commons of the western Indian Himalayas: a case study of differences. Presented at Voices from the Commons, the Sixth Biennial Conference of the International Association for the Study of Common Property. June 5-8, Berkeley, California, USA.

Doss, C. R. 2001. Designing agricultural technology for African women farmers: lessons from 25 years of experience. World Development 29:2075-2092.

Ejembi, E. P., S. A. Ejembi, and O. N. Abgulu. 2006. Food chain activities of women in an agrarian community in Central Nigeria: implications for rural development. Journal of Human Ecology 19 (1):63-67.

Gbadegesin, A. 1996. Management of forest resources by women: a case study from the Olokemeji Forest Reserve area, southwestern Nigeria. Environmental Conservation 23(2):115-119.

German, L., W. Mazengia, S. Ayele, W. Tirwomwe, J. Tanui, H. Taye, L. Begashaw, S. Nyangas, A. Chemangeni, W. Cheptegei, M. Tsegaye, Z. Admassu, F. Alinyo, A. Mekonnen, K. Aberra, T. Tolera, Z. Jotte, and K. Bedane. 2008. Enabling equitable collective action and policy change for poverty reduction and improved natural resource management in the eastern African highlands. Collective Action and Property Rights (CAPRi) Working Paper 86. International Food Policy Research Institute, Washington, D.C. USA.

Gibson, C., J. T. Williams, and E. Ostrom. 2005. Local enforcement and better forests. World Development 33(2):273-284.

Howard, P. L., editor. 2003. Women and plants: gender relations in biodiversity management and conservation. Zed Books, London, UK.

Howard, P. L., and G. Nabanoga. 2007. Are there customary rights to plants? An inquiry among the Baganda (Uganda), with special attention to gender. World Development 35(9):1542-1563.

Jackson, C. 1993. Doing what comes naturally? Women and environment in development. World Development 21(12):1947-1963.

Jewitt, S. 2000. Unequal knowledges in Jharkhand, India: de-romanticizing women's agroecological expertise. Development and Change 31(5):961-985.
Johnson, C. O. 2003. Nigeria: illegal logging and forest women's resistance. Review of African Political Economy 30(95):156-162.

Jumbe, C. B. L., and A. Angelsen. 2007. Has forest co-management in Malawi benefited the poor? Pages 171-199 in N. Dinello and V. Popov, editors. Political institutions and development: failed expectations and renewed hopes. Edward Elgar, Cheltenham, UK.

Kaimowitz, D., and A. Angelsen. 1998. Economic models of tropical deforestation: a review. Center for International Forestry Research, Bogor, Indonesia.

Komarudin, H., J. Siagian, and C. Colfer. 2008. Collective action to secure property rights for the poor: a case study in Jambi Province, Indonesia. Collective Action and Property Rights (CAPRi) Working Paper No. 90. International Food Policy Research Institute, Washington, D.C. USA.

Locke, C. 1999. Constructing a gender policy for joint forest management in India. Development and Change 30(2):265-285.

Mackenzie, F. 1995. A farm is like a child who cannot be left unguarded: gender, land and labor in Central Province, Kenya. IDS Bulletin-Institute of Development Studies 26(1):17-23.

Marchetti, T. 1997. Sustainable forest management and gender equality: women and forests. INSTRAW 26:23-7.

Meinzen-Dick, R., L. Brown, H. Feldstein, and A. Quisumbing. 1997. Gender, property rights and natural resources. World Development 25 (8):1305-1315.

Mwangi, E., R. R. Meinzen-Dick, and Y. Sun. 2009. Does gender influence forestry management? Exploring cases from East Africa and Latin America. CID Graduate Student and Research Fellow Working Paper No. 40. Center for International Development, Harvard University, Cambridge, Massachusetts, USA. [online] URL: http://www.hks.harvard.edu/var/ezp site/storage/fckeditor/ file/pdfs/centers-programs/centers/cid/publications/ student-fellows/wp/040.pdf. 
Nagendra, H. 2007. Drivers of reforestation in human-dominated forests. Proceedings of the National Academy of Sciences 104(39):15218-15223.

Nuggehalli, R. K., and L.S. Prokopy. 2009. Motivating factors and facilitating conditions explaining women's participation in co-management of Sri Lankan forests. Forest Policy and Economics 11(4):288-293.

Odebode, S. O. 2005. Gender issues in community forestry: lessons from Nigeria. Journal of Food, Agriculture and Environment 3(2):307-312.

Oloruntoba, A., and O. Adetokunbo. 2006. Determinants of households' participation in social forestry in a zone of Northern Nigeria. Journal of Food, Agriculture and Environment 4(2):320-326.

Ostrom, E. 1990. Governing the commons: the evolution of institutions for collective action. Cambridge University Press, Cambridge, UK.

Pandey, D. 1993. Empowerment of women for environmentally sustainable development through participatory action research. In S. Ahmed, editor. Gendering the rural environment: concepts and issues for practice. Workshop report \#11. Institute of Rural Management Anand, India.

Pandolfelli, L., R. Meinzen-Dick, and S. Dohrn. 2007. Gender and collective action: a conceptual framework for analysis. Collective Action and Property Rights (CAPRi) Working Paper No. 64. International Food Policy Research Institute, Washington, D.C., USA.

Place, F. 1995. The role of land and tree tenure on the adoption of agroforestry technologies in Zambia, Burundi, Uganda, and Malawi: a summary and synthesis. Land Tenure Center, University of Wisconsin, Madison, Wisconsin, USA.

Quisumbing, A. R., E. Payongayong, J. B. Aidoo, and K. Otsuka. 2001. Women's land rights in the transition to individualized ownership: implications for tree-resource management in western Ghana. Economic Development and Cultural Change 50:157-181.

Rai, B., and M. Buchy. 2004. Institutional exclusion of women in community forestry: Is women-only strategy a right answer? Pages 399-408 in K. R. Kanel, P. Mathema, B. R. Kandel, D. R. Niraula, A. R. Sharma, and M. Gautam, editors. Twenty-five years of community forestry: contribution to millennium development goals. Proceedings of the Fourth National Conference of Community Forestry, Kathmandu, Nepal.

Resurreccion, B. P. 2006. Gender, identity and agency in Philippine upland development. Development and Change 37(2):375-400.

Shanley, S., and G. R. Gaia. 2001. Equitable ecology: collaborative learning for local benefit in Amazonia. Agriculture Systems 73:83-97.

Sultana, P., and P. Thompson. 2006. Gender and local floodplain management institutions: a case study from Bangladesh. Collective Action and Property Rights (CAPRi) Working Paper 57. International Food Policy Research Institute, Washington, D.C., USA.

Tinker, I. 1994. Women and community forestry in Nepal: expectations and realities. Society and Natural Resources 7(4):367-381.

Torri, M. C. 2010. Power, structure, gender relations and community-based conservation: the case study of the Sariska region, Rajasthan, India. Journal of International Women's Studies 11(4):1-18.

van Kooten, G. C., H. W. Nelson, and I. Vertinsky. 2005. Certification of sustainable forest management practices: a global perspective on why countries certify. Forest Policy and Economics 7(6):857-867.

Watkins, C. A. 2009. Natural resource use strategies in a forest-adjacent Ugandan village. Human Ecology 37(6):723-731.

Westermann, O., J. Ashby, and J. Pretty. 2005. Gender and social capital: the importance of gender differences for the maturity and effectiveness of natural resource management groups. World Development 33(11):1783-1799.

Yadama, G. N., B. R. Pragada, and R. R. Pragada. 1997. Forest dependent survival strategies of tribal women: implications for joint forest management in Andhra Pradesh, India. RAP Publication 1997/24. Regional Office for Asia and the Pacific. Food and Agriculture Organization, Bangkok, Thailand.

[1] This number is from average marginal effect, which is not shown in the regression result. 